Отримано: 14 квітня 2018 р.

Прорецензовано: 20 квітня 2018 р.

Прийнято до друку: 03 травня 2018 р.

e-mail: mirka.nowak@poczta.onet.pl

DOI: $10.25264 / 2311-5149-2018-9(37)-16-20$
Nowak M. M., Dziekański P. Changes in Poland's agriculture as an example of socially responsible business. Наукові записки Начіонального університету «Острозька академія». Серія «Економіка» : науковий журнал. Острог : Вид-во НаУОА, червень 2018. № 9(37). C. 16-20.

УДК: 338.43 .02

JEL-Classification: $Q 1, R 0$

Mirosława Marzena Nowak, Ph. D.,

Jan Kochanowski University in Kielce, Piotrków Trybunalski Campus

Pawel Dziekański, Ph. D.,

Jan Kochanowski University in Kielce

\title{
CHANGES IN POLAND'S AGRICULTURE \\ AS AN EXAMPLE OF SOCIALLY RESPONSIBLE BUSINESS
}

The article presents the changes in Poland's agricultural sector as an example of socially responsible business. The material was generated on the basis of data from the Central Statistical Office of Poland and secondary sources. It became apparent that key elements of the 'corporate social responsibility' (CSR) concept are shared with the models for multifunctional and sustainable agriculture which is manifested in ecologic and sustainable farming. Generally, the number of the farms under research rose from 1,463 in 2005, to 19,813 in 2015. Subsequently, employment also rose in this sector i.e. the difference between 2005 and 2015 was 249,000 people. It should be noted that the assessment of socially responsible activity is difficult when considering changes in agriculture.

Key words: corporate social responsibility, rural areas, sustainable development.

\section{Mirosława Marzena Nowak, Ph. D.}

Jan Kochanowski University in Kielce, Piotrków Trybunalski Campus

Paweł Dziekański, Ph. D.

Jan Kochanowski University in Kielce

\section{ZMIANY W ROLNICTWIE JAKO PRZYKLAD SPOLECZNIE ODPOWIEDZIALNEGO BIZNESU}

W artykule przedstawiono zmiany $w$ rolnictwie jako przykład społecznie odpowiedzialnego biznesu. Opracowanie przygotowano w oparciu o materiały i dane źródtowe GUS oraz dostępne źródła wtórne. Stwierdzono, że kluczowe elementy koncepcji społecznej odpowiedzialności biznesu (CSR) sq wspólne z modelami wielofunkcyjnego i zrównoważonego rolnictwa. Zrównoważenie rolnictwa przejawia się $m$. in. w rolnictwie ekologicznym i zrównoważonym. Ogólnie stwierdzono, że liczba tych gospodarstw rośnie z 1463 w 2005 r. do 19813 w 2015 r. Wzrasta także liczba pracujacych w rolnictwie. Różnica między rokiem 2005 a rokiem 2015 wyniosła 249 tys. osób. Stwierdzić należy, że ocena działań spolecznie odpowiedzialnych uwzględniajac zmiany $w$ rolnictwie jest trudna.

Stowa kluczowe: społeczna odpowiedzialność biznesu, obszary wiejskie, zrównoważony rozwój.

\author{
Новак Мирослава Мажена, \\ доктор філософії \\ Університет ім. Яна Кохановського у Кельце, Філіал у Пьотркові Трибунальському \\ Джєканьський Павел, \\ доктор філософіі \\ Університет ім. Яна Кохановського у Кєльце

\section{ЗМІНИ У ПОЛЬСЬКОМУ СІЛЬСЬКОМУ ГОСПОДАРСТВІ ЯК ПРИКЛАД СОЦІАЛЬНО ВІДПОВІДАЛЬНОГО БІЗНЕСУ}

Ця стаття представляє зміни в сільському господарстві Польщі як приклад соиіально відповідального бізнесу. Матеріал був опращьований на основі інформачії, отриманої від Центрального Відділу Статистики Польщі та з другорядних джерел. Виявилося очевидним, щзо ключові елементи концепції «корпоративної сочіальної відповідальності» (CSR) співставні з моделями багатофункиіонального і збалансованого сільського господарства, щчо відображається в екологічному $і$ збалансованому фермерському господарюванні. Загалом кількість таких фермерських господарств зросла від 1463 у 2005 роиі до 19813 у 2015 роиі. Також зросла кількість зайнятих у изьому секторі, наприклад, різниия між 2005 і 2015 роками склала 249000 прачівників. Слід зауважити, щчо очінка сочіально відповідальної діяльності є важким завданням під час розгляду змін у сільському господарстві.

Ключові слова: корпоративна сочіальна відповідальність, сільські місчевості, зрівноважений розвиток. 


\section{Introduction}

The idea of 'corporate social responsibility' (CSR) is tied to voluntary implementation of certain changes such as economic strategy and improved communication whose goals are to improve the well-being of the community and care for the environment. The term 'sustainable management' surfaces frequently as a synonym for CSR which in fact means management in accordance with 'sustainable development' (Levytska, WrzesińskaKowal, 2013, p. 171-172). Two fundamental components are distinguished in the CSR concept i.e. balanced activities in the area of environmental protection (environmental sustainability), and in human relations (human sustainability) (Kryk, 2000, p. 117-127; Heslin, Ochoa 2008, p. 125-144). This concept not only requires fulfilling legal obligations but also surpassing those same obligations. The concept of sustainable development stresses the need for mutual responsibility and solidarity by current and future generations for the condition and protection of the environment which finds its voice in ecological ethics (Kryk, 2000, p. 117-127; Kryk, 2011, p. 255), regarding harmonizing three levels of activity - economical, societal and ecological (Bujanowicz-Haraś, 2007, p. 162-167). With this in mind, key elements of the CSR concept correspond to those of multi-functional and sustainable agriculture (Chlebicka, 2010, p. 11)). The evolution of this type of development does not lead to environmental degradation but to utilizing appropriate technology, soil, water, plant and animal resource conservation. It is development that ensures economic durability for farming and community approval while realizing production and ecological objectives (Wilkin, 2008, p. 9-20). The objective of this project is to demonstrate changes in Poland's agriculture as examples of corporate social responsibility. The work is prepared on the basis of materials and data from the Central Statistical Office of Poland and available secondary sources.

\section{Selected Changes in Poland's Agriculture as Examples of Corporate Social Responsibility}

The contemporary interpretation of 'corporate social responsibility' (CSR) is clearly tied to the concept of sustainable and durable development (Paliwoda - Matiolańska, p. 255). In this context, sustainable development of agriculture and rural areas is a critical segment of the general concept of sustainable development as agriculture is a major keeper of the natural environment. Sustainable development in regard to farming enables, among others, soil conservation and the preservation of plant and animal genetics (Wilkin, 2004, p. 157-170; Piwowar, 2013, p.144). Sustainable management may occur as ecological farming or integrated; also known as sustainable (Grontkowska, Klepacki, 2006; Maciulewski, 2008, p. 53). During the examination of changes in Poland's agriculture as example of CSR, attention was given to the number of ecologic farms and their area (Table 1). It was noted during the study period that up to 2014, the number and area of ecologic farms rose from 2005; however, 2015 showed a drop in the number and area of ecologic farms as compared to 2014 - down 1200 farms and 54,000 hectares, respectively.

Ecologic Farms in Poland: 2005 to 2015

Table 1

\begin{tabular}{|c|c|c|c|c|}
\hline \multirow{2}{*}{ Year } & \multicolumn{2}{|c|}{ Certified } & \multicolumn{2}{c|}{ Under conversion } \\
\cline { 2 - 5 } & farms & agricultural area in ha & Under conversion & agricultural area in ha \\
\hline 2005 & 1,463 & 38,673 & 5,719 & 127,627 \\
\hline 2010 & 12,901 & 308,095 & 7,681 & 210,974 \\
\hline 2013 & 19,872 & 492,972 & 6,726 & 176,998 \\
\hline 2014 & 21,020 & 555,898 & 3,809 & 102,004 \\
\hline 2015 & 19,813 & 501,925 & 2,464 & 78,805 \\
\hline
\end{tabular}

Source: own on the basis of RSR 2016, p. 112.

Examining farms utilizing integrated farming methods (Table 2), it was noted that the highest number to be declared occurred in 2005, and the least in 2010. Regarding certified integrated farms, the highest recording occurred in 2014; in 2015, noted was an increase in hectarage - an increase of 13,665 ha from 2010.

Table 2

Poland's Farms Using Integrated Farming Methods

\begin{tabular}{|c|c|c|c|c|c|}
\hline Specyfication & $\mathbf{2 0 0 5}$ & $\mathbf{2 0 1 0}$ & $\mathbf{2 0 1 3}$ & $\mathbf{2 0 1 4}$ & $\mathbf{2 0 1 5}$ \\
\hline Number of holdings & & & & & \\
\hline reported & 4,443 & 1,405 & 2,671 & 2,953 & 2,835 \\
\hline certified & 1,557 & 1,068 & 2,898 & 3,178 & 3,137 \\
\hline Certified area in ha. & 9,286 & 7,589 & 18,317 & 19,380 & 21,254 \\
\hline \multicolumn{5}{|l|}{ Source: } \\
\hline
\end{tabular}

Source: RSR 2016, p. 113.

It should be remembered that the changes in rural areas are dependent on the rating and type of farming for said region and micro-region. The fundamental economic measure in agriculture is the farm where maximized 
income is paramount and at the same time is a place of employment for family members which guarantees basic livelihood (Otoliński, Wielicki, 2003, p. 103-119). With this in mind, the analysis of changes in farming with regard to CSR, scrutiny of agricultural employment is in order (table 3). Steady rise in agricultural employment was confirmed: the difference in employment of 2015 to 2005 was 249,000 workers. Furthermore, the rise of women employed in agriculture is also evident: from 923,300 in 2005, to 1,130,900 in 2015. A similar tendency was evident for employers and self-employed individuals working on independent farms - growth of 249,200 men from 2005 to 2015 and 195,100 women for the same period.

Table 3

Agricultural Employment by Employment Status (in thousands) as of December 31

\begin{tabular}{|lc|c|c|c|c|c|}
\hline \multicolumn{1}{|c|}{$\begin{array}{c}\text { Specyfication } \\
\text { o- total } \\
\text { k- of which women }\end{array}$} & $\mathbf{2 0 0 5}$ & $\mathbf{2 0 1 0}$ & $\mathbf{2 0 1 3}$ & $\mathbf{2 0 1 4}$ & $\mathbf{2 0 1 5}$ \\
\hline Total & $\mathrm{o}$ & $2,082.2$ & $2,326.2$ & $2,326.7$ & $2,331.4$ & $2,331.2$ \\
Women & $\mathrm{k}$ & 923.3 & $1,118.9$ & $1,127.4$ & $1,130.6$ & $1,130.9$ \\
\hline Employed on the basis of an employment contract - $-\mathrm{o}$ & 99.0 & 97.4 & 99.2 & 104.3 & 104.7 \\
Women & $\mathrm{k}$ & 28.3 & 29.7 & 38.4 & 41.7 & 42.2 \\
\hline Employers and own-account workers on & & & & & & \\
private farms in agriculture & $\mathrm{o}$ & $1,967.0$ & $2,216.2$ & $2,216.2$ & $2,216.2$ & $2,216.2$ \\
Women & $\mathrm{k}$ & 890.5 & $1,085.6$ & $1,085.6$ & $1,085.6$ & $1,085.6$ \\
\hline
\end{tabular}

Source: RSR 2016, p. 126.

The subsequent item to be scrutinized in this study was the available average monthly income for households. Reviewing the data in table 4, available monthly income rose from 2,155.69 PLN (per person) in 2005, to $3,885.36$ PLN for same in 2015. It was found that income for farmer households varied from year to year when compared to employee households: in 2005 and 2015 farmer household income was lower, but in the remaining years higher. the greatest difference showed in 2013, on the side of farmer households.

Average Available Monthly Household Income per Person (in PLN)

\begin{tabular}{|l|c|c|c|c|c|}
\hline \multicolumn{1}{|c|}{ Specification } & $\mathbf{2 0 0 5}$ & $\mathbf{2 0 1 0}$ & $\mathbf{2 0 1 3}$ & $\mathbf{2 0 1 4}$ & $\mathbf{2 0 1 5}$ \\
\hline Total & $\mathbf{2 , 1 5 5 . 6 9}$ & $\mathbf{3 , 3 7 2 . 5 1}$ & $\mathbf{3 , 6 4 7 . 0 3}$ & $\mathbf{3 , 7 6 3 . 5 5}$ & $\mathbf{3 , 8 8 5 . 3 6}$ \\
\hline Employee households & $2,598.15$ & $3,996.47$ & $4,289.01$ & $4,449.23$ & $4,550.74$ \\
\hline Farmer households & $2,595.44$ & $4,477.11$ & $5,043.97$ & $4,568.09$ & $4,496.24$ \\
\hline
\end{tabular}

Source: RSR 2016, p. 224.

Measuring the level of agricultural sustainability has certain specificity which makes sustainability indicators difficult to select. Above all, agriculture (agricultural activity) can both degrade and destroy the natural environment, or preserve and protect said environment, or even create natural assets (Zegar, 2009, p. 18). The representation of the above statement is shown in the data of Table 5. The analysis of the data indicates that degraded and devastated land area was greatest in 2005 i.e. 64,978 hectares (ha). The sum total of this land over the study period was over 314,245 ha of which 9,002 ha were re-cultivated for farming $(4,729 \mathrm{ha})$, and forestry $(2,069 \mathrm{ha})$. For the study period, 3,962 ha were utilized: 1,897 ha for farming and 746 ha for forestry. These activities qualify for CSR and sustainable development as they pertain to environment protection and indirectly affect social and economic aspects.

Table 5

\section{Degraded and Devastated Land Requiring Reclamation and Management as well as Reclaimed and Managed Land (in hectares)}

\begin{tabular}{|l|c|c|c|c|c|}
\hline \multicolumn{1}{|c|}{ Specification } & $\mathbf{2 0 0 5}$ & $\mathbf{2 0 1 0}$ & $\mathbf{2 0 1 3}$ & $\mathbf{2 0 1 4}$ & $\mathbf{2 0 1 5}$ \\
\hline Degraded and devastated land & 64,978 & 61,161 & 61,958 & 62,774 & 63,374 \\
\hline Reclaimed land (during the year) & 1,861 & 1,222 & 1,941 & 2,171 & 1,807 \\
\hline for agricultural purposes & 555 & 634 & 1,132 & 1,146 & 1,262 \\
\hline for forestry purposes & 608 & 440 & 235 & 504 & 282 \\
\hline Managed land (during the year) & 1,132 & 581 & 697 & 700 & 852 \\
\hline for agricultural purposes & 374 & 299 & 369 & 369 & 486 \\
\hline for forestry purposes & 266 & 212 & 59 & 111 & 98 \\
\hline
\end{tabular}

Source: own on the basis of RSR, 2005,p. 96; 2016, p. 126.

Sustainable agriculture, and key elements of CSR, establish the response to industrial agriculture which unwaveringly pursues higher food production at the cost of the environment. 
Implementing the idea of CSR into farms may improve farmers' awareness of ecology, understanding not just certain prohibitions and proscriptions, or behaving 'politically correctly', but to exhibit genuine regard for the natural environment. In the issue of environmental protection, farmers' cognizance of ecology is key. Only high awareness, expressed in attitudes and application of management practices, will enhance proper relations of human/environment and economics/environment (Brodzińska, 2011, p. 34-38). Furthermore, the agricultural producer can become a participant of CSR as a supplier of socially responsible processors or foodstuff distributors. As a result of advantageous commercial position in negotiations, large retailers or processing companies can encourage producers to implement various aspects of socially responsible behavior (Chlebicka, 2010, p. 11).

Sustainability of farms is not synonymous with agricultural sustainability: the assessment of farm sustainability and agriculture requires somewhat different measures. In the case of farms, the baseline should reflect environmental values i.e. components pertaining to maintenance of soil culture and long-term capability of biomass production. As indicators of sustainability regarding economics, farm generated income and/or production costs could be applied. An additional economic sustainability indicator could be effective use of material and non-material resources. In terms of social sustainability indicators, those referring to lifestyle could be applied e.g. material, educational, health, public and individual safety, environmental quality or justice (Zegar, 2009, p. 18-19).

\section{Conclusion}

The assessment of socially responsible activities by entitles operating in the market is especially difficult and it applies to farms as well. From research carried out by Brodzińska, it is apparent that the criteria used to monitor farms carrying out requirements of agri-environmental programs, does not guarantee implementation of environmentally friendly practices (Brodzińska, 2013, p. 84-85). As a result it is difficult to categorically confirm whether increasing the number of production farms adhering to ecologic methods or integrated methods is socially responsible. This reality also pertains to changes in the numbers of those working in agriculture in view of employment status and other changes in agriculture.

The difficulties of initiating the concept of sustainable agricultural and rural development arise from social, intellectual and ethical issues (Atoszek, 2002, p. 197-209). Farming is the primary user of land and space, and it produces foodstuffs as well as non-foodstuffs, impacts on the natural environment and landscape (positive and negative), and maintains the vitality of rural communities. By this virtue, farming has an important role in the processes of sustainable (read durable) development impacting on every constituent part of rural viability (Zegar, 2009, p. 9-13). The sustainability of agriculture can be approached from the perspective of the global scale, or regional or individual farm (Krasowicz, 2006, p. 25-263). And yet it should be noted that even though the essence of sustainability is important for each level, the measurements vary thereof (Brodzińska, 2013, p. 81).

\section{Literature:}

1. Levytska G., Wrzesińska-Kowal J. (2013), Społeczna odpowiedzialność biznesu w działalności przedsiębiorstw gastronomicznych w Polsce, «Scientific Journal of Warsaw University of Life Sciences (SGGW)», Economics and Orgainzation of Agri-Food Sector, No. 104 p. 171-183.

2. Atoszek J. (2002), Koncepcja zrównoważonego rozwoju i szanse jej realizacji na obszarach wiejskich Lubelszczyzny (on the basis of surveys), Annales UMCS, Lublin, Section B, vol. 57, 11, p. 197-209.

3. Brodzińska K, (2013), Problemy społecznej odpowiedzialności w rolnictwie, «Polityki Europejskie, Finanse i Marketing», No.10 (59), p. 79-86.

4. Brodzińska K. (2011), Świadomość ekologiczna rolników a praktyka gospodarowania, «Roczniki Naukowe SERiA», vol. 14, jour. 5, p. 34-38.

5. Bujanowicz-Haraś B. (2007), Wybrane problemy ekologiczne na obszarach wiejskich w kontekście rozwoju zrównoważonego, «Ochrona Środowiska i Zasobów Naturalnych», No. 33, p. 162-167.

6. Chlebicka A. (2010), Koncepcja społecznej odpowiedzialności; wkład do debaty nad przyszłością Wspólnej Polityki Rolnej, «Scientific Journal of Warsaw University of Life Sciences (SGGW)Problems of World Agriculture», vol. 10, (XXV), jour. 4, p. 5-11.

7. Grontkowska B, Klepacki B. (2006), Ekonomika i zarządzanie przedsiębiorstwem w agrobiznesie, Format-AB, Warsaw.

8. GUS Rocznik statystyczny rolnictwa, 2006, 2016.

9. Heslin P.A., Ochoa J.D. (2008), Understanding and developing strategic corporate social responsibility, «Organizational Dynamics», vol. 37, No. 2, p. 125-144.

10. Krasowicz S, (2006), Sposoby realizacji zrównoważonego rozwoju w gospodarstwie rolnym, «Zeszyty Naukowe AR we Wrocławiu», No. 540, p. 25-263.

11. Kryk B. (2011), Raportowanie społecznej odpowiedzialności przedsiębiorstw za środowisko przyrodnicz, «Zeszyty Naukowe Uniwersytetu Szczecińskiego», no. 625, FINANSE, RYNKI FINANSOWE, UBEZPIECZENIA, No. 32, p. 253-269. 
12. Kryk B. (2000), Etyka ekologiczna a społeczna odpowiedzialność przedsiębiorstwa, Teorie i aplikacje etyki gospodarczej, ed. B. Pogonowska, AE w Poznań, p. 117-127.

13. Levytska G., Wrzesińska-Kowal J. (2013), Społeczna odpowiedzialność biznesu w działalności przedsiębiorstw gastronomicznych w Polsce, «Scientific Journal of Warsaw University of Life Sciences (SGGW) Economics and Orgainzation of Agri-Food Sector», No. 104 p. 171-183.

14. Maciulewski B. (2008), Rolnictwo zrównoważone na obszarach przyrodniczo cennych Suwalszczyzny, «Ochrona Środowiska i Zasobów Naturalnych», No. 35/36, p. 53-57.

15. Otoliński E.,Wielicki W. (2003), Kierunki rozwoju wsi i gospodarstw rolnych, «Roczniki Akademii Rolniczej w Poznaniu» - CCCLVIII , Ekon. No. 2, p. 103-119.

16. Paliwoda - Matiolańska A., Społeczna odpowiedzialność biznesu w teorii i praktyce, «Prace Instytutu Lotnictwa», No. 1 (222), p. 253-265.

17. Piwowar A. (2013), Zarys problematyki nawożenia w zrównoważonym rozwoju rolnictwa w Polsce, «Ekonomia i Środowisko», No. 1(44), p.143-155.

18. Wilkin J. (2004), Dlaczego potrzebujemy długookresowej strategii zintegrowanego rozwoju wsi i rolnictwa w Polsce, «Wieś i Rolnictwo», No. 2, p. 157-170.

19. Wilkin J. (2008), Wielofunkcyjność rolnictwa i obszarów wiejskich, Wyzwania przed obszarami wiejskimi i rolnictwem w perspektywie lat 2014-2020, ed. M. Kłodziński, IRWiR PAN, Warsaw, p. 9-20.

20. Zegar J. (2009), Z badań nad rolnictwem społecznie zrównoważonym. Raport końcowy, synteza i rekomendacje. IERiGŻ PAN, Warsaw, p. 9-13. 